DOI: $10.2478 / \mathrm{v} 10122-012-0003-3$

\title{
ENGLISH-INDUCED CHANGES TO URBAN COLLOQUIAL HINDI LEXICON AND STRUCTURE. MIXED SPEECH AS A MODE OF DISCOURSE
}

\author{
TOMASZ BOROWIAK
}

\begin{abstract}
Tomasz Borowiak. English-Induced Changes to Urban Colloquial Hindi Lexicon and Structure. Mixed Speech as a Mode of Discourse. Lingua Posnaniensis, vol. LIV (1)/2012. The Poznań Society for the Advancement of the Arts and Sciences. PL ISSN 0079-4740, ISBN 978-83-7654-103-7, pp. 35-44.

This article aims at describing some of the lexical and grammatical innovations observed in Hindi as a result of English impact. We investigate some crucial aspects of English noun borrowing and further along discuss some other phenomena that occur in Hindi due to the language contact, e.g. preposition transfer and hybridization. The data for this research consists of internet newspaper excerpts, samples from Indian film and radio speech. We try to show that English influence has far reaching effects on Hindi lexicon and structure. The conclusion to be drawn from the present investigation is that the intense interaction between English and Hindi may be the initial step towards the creation of an interlanguage located somewhere between the two languages in question.
\end{abstract}

Tomasz Borowiak, Institute of Linguistics, Adam Mickiewicz University, al. Niepodległości 4, PL 61-874 Poznań

This study explores some of the lexical and grammatical aspects of English impact observed in the middle-class colloquial variety of Hindi. English and Hindi as official languages of India have coexisted within the same linguistic area for decades. This kind of extensive language contact situation always causes some form of interaction to occur.

A number of important observations as regards English influence on Hindi have been already made in Kachru (e.g. 1978, 1986), but also Verma (1976). ${ }^{1}$ These pioneering works aiming to highlight diverse manifestations of Hindi Englishization, as the process of English impact on Hindi came to be termed ${ }^{2}$, were meant, however, as preliminary

1 Englishization also involved other languages of the Subcontinent, e.g. Oriya Bengali, Telugu, Kannada, etc. Patnaik \& PANDit (1986: 232), for instance, claim that during last 500 hundred years Oriya came in contact with a number of Indian and foreign languages, but English is the language that influenced it the most significantly and extensively. The foreign influence is not confined to the lexicon, as for example, it includes the impersonal passive. SRIDHAR \& SRIDHAR (1978b) in turn discuss English and Kannada interaction.

2 KACHRU (1986: 155) notes that the term 'Anglicization' has some special connotations in India, thus he proposes a neutral one - 'Englishization' instead. 
attempts to illustrate certain aspects of the the process in question. Yet it is puzzling to note that very few studies have ever since dealt with the contact induced changes in a systematic way. Moreover, there are numerous innovations to be observed in the lexical and structural level of Hindi, and especially in its urban incarnation, that are hitherto unattested in the literature. An inquiry into some of these novelties is the major subject of the present study. ${ }^{3}$

The basic data for this research consists of language samples from Indian film and radio speech, along with internet newspaper excerpts. All three data sources supply vast amount of material for linguistic analysis. Generally speaking, Englishized Hindi employed in the radio, film and newspaper may both reflect the variety spoken in Northern India, or, at the same time may be creating this variety by setting trends for language choice and use, at least, in the urban, middle-class society. In any case, the newspaper and the movie language together with the all-pervasive radio language leave no (urban) speakers unaffected. ${ }^{4}$ As a result, we have at hand a fair indicator of actual language patterns prevalent in Northern India.

The first contact induced change in $\mathrm{UCH}$ to be addressed here refers to the declension patterns and the flectional system of Hindi as far as English-origin nouns assigned to masculine gender are concerned. In general, such nouns fall into either of two declensional subtypes existent in the standard variety. ${ }^{5}$ However, apart from borrowings that do not introduce any innovation, but inflect according to the grammar of the standard variety, there occur some nouns that have endings that are atypical in Hindi. These novel nominal (vowel) endings $(-e$ and $-o$ ) appear in singular direct case. The following tables are illustrative.

Table 1. Nouns with the atypical -e termination

\begin{tabular}{|c|c|c|c|c|}
\hline English Noun & Hindi Spelling & $\begin{array}{c}\text { Plural } \\
\text { Non-Oblique }\end{array}$ & \multicolumn{2}{|c|}{ Plural Oblique } \\
\hline Birthday & barthde & -- & -- & or barthdeyõ? \\
\hline Cafe & $k \bar{a} f e$ & -- & -- & or kāfeyõ? \\
\hline Clay & kle & -- & -- & or kleyõ? \\
\hline Day & de & -- & --- & or $\operatorname{dey} \tilde{o} ?$ \\
\hline Display & disple & -- & -- & or displeyõ? \\
\hline Highway & hāive & -- & -- & or hāiveyõ? \\
\hline Resume & rizyūme & -- & --- & or rizyūmeyõ? \\
\hline Spray & spre & -- & -- & or spreyõ? \\
\hline Survey & sarve & sarve &.- & or sarveyõ? \\
\hline Way & & -- & -- & or veyõ? \\
\hline X-Ray & eks-re & -- &.- & or eks-reyõ? \\
\hline
\end{tabular}

3 Urban, colloquial Hindi (hereafter UCH) is a term proposed here for the variety of Hindi ordinarily employed by urban speakers, in which English influences are omnipresent.

4 Bhatia \& Ritchie (2005: 783) claim Hindi films and the mass media in the twentieth century played a significant role in the spread of Hindi/Urdu. It is not unreasonable to think films and media at the same time promoted Englishized Hindi.

5 Hindi nominal flexion normally distinguishes between non-oblique or direct and oblique cases in both singular and plural. The oblique forms of singular masculine are identical as direct plural forms and for the sake of convenience remain unmentioned when discussing the flexional paradigms. 
Table 2. Nouns with the atypical -o termination ${ }^{6}$

\begin{tabular}{|c|c|c|c|c|}
\hline English Noun & Hindi Spelling & $\begin{array}{c}\text { Plural } \\
\text { Non-Oblique }\end{array}$ & \multicolumn{2}{|c|}{ Plural Oblique } \\
\hline Bureau & byūro & -- & byйтrõ & or byūrõo? \\
\hline Cargo & kārgo & $\ldots$ & kārgoõ & or kārgõ? \\
\hline Ceo & $s \overline{\imath \imath} O$ & $-\ldots$ & 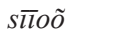 & or $s \bar{\imath} \bar{o} \tilde{?} ?$ \\
\hline Embargo & imbārgo & $-\ldots$ & imbārgoõ & or imbārgõ? \\
\hline Eyebrow & äibro & - - - & äibroõ & or āibrõ? \\
\hline Show & sho & $-\ldots$ & shoõ & or shô? \\
\hline Studio & sțūdiyo & - & sțūdiyoõ & or sḍüdiyõ? \\
\hline Veto & vìțo & -- & vìtoõ & or vițtô? \\
\hline Video & vidiliyo & -- & vidìyoõ & or vididyõ? \\
\hline Window & vindo & -- & viṇdoõ & or vinḍô? \\
\hline
\end{tabular}

In the standard variety $-e$ ending is restricted for singular oblique or plural direct cases of masculine gender only. Thus nouns that terminate with $-e$ in the singular direct case establish a precedent and a novelty in the flectional system of the RL. As for - $o$ termination, there are no nouns in Hindi that assume such ending. For the time being we have too little data to elicit how the nouns listed out above are likely to inflect (i.e which of the the two possible variants of plural oblique case is to dominate over the other). The only examples recorded are given below. ${ }^{7}$

$$
\begin{aligned}
& \text { bād mẽ aisī photoõ } k \bar{\imath} \text { lagtīhai pradarshanī. } \\
& \text { later in such OBL GEN-f put-PRES exhibition }
\end{aligned}
$$

Then there is an exhibition of these/such photos.

(GOOGLE HINDI)

$\begin{array}{lllllll}\text { unkāa } & \bar{a} r o p & \text { hai } & k i & \text { un } & \text { photõ se } & \text { hìrāpāl ne } \\ \text { 3.PL-POSSESS accusation } & \text { be-PRES that } & \text { 3.PLOBL } & \text { with } & \text { (name) ERG }\end{array}$

His accusation was that Hirapal...

use dhamākar blekmel kiyā.

3.SG-DAT threaten-ABS do-SIMP-PERF

...blackmailed him with the photos.

(DBH 30/08/07)

Yet another novelty in the standard declensional patterns occurs with the introduction of nouns of masculine gender that found declinable in accordance to both masculine declination subtypes. Consider the following examples.

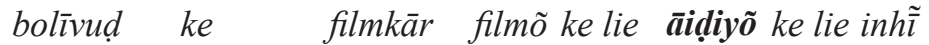

$$
\begin{aligned}
& \text { GEN-m-PL film maker for for 3.PL-DEM-OBL-EMPH } \\
& \text { Bollywood film makers seem to be... }
\end{aligned}
$$

6 Some nouns listed here may be actually of double gender e.g. sīo (CEO). Although such nouns may take both agreements, they are likely, if at all, to follow masculine declination patterns, as e.g. SH double gender nouns like rāsțtrpati 'president' or pradhān mantrī 'prime minister'.

7 The following abbrevaitions are used throughout this article: ABS - absolutive participle, CAUS II - double causative, COMP comparative, DAT - dative, DEM - demonstrative, EMPH - emphasis, ERG - ergative, f. - feminine, FUT - future, GEN - genitive, HAB - habitual tense, HON - honorific, m. - masculine, NEG negative, NONOBL - non-oblique, OBL - oblique case, PERF - perfective, PL - plural, POSSESS - possessive, PRES - present, PRESUMPT - presumptive, PROG - progressive - REFL - reflexive, REL - relative, SG - singular, SIMP - simple, SUBJ - subjunctive, VN - verbal noun. 


\section{ḍ̄vịuiyõ par burī tarah nirbhar hote haĩ on bad way dependent HAB-PRES-PL}

...badly dependent on the ideas from the [foreign] DVDs.

(AU 18/01/08)

(4)
[...] vicitr șadyantr ke sāth äiḍiyā̃̃ mẽ nicor kiyāhai. surprising plot with in extract do-PERF-PRES

[...] together with the unusual plot, [great] ideas have been selected.

(BSA 17/01/08)

In the examples given above, two different forms of plural oblique case (äidiyõ and $\bar{a} i d i y \bar{a} \tilde{o}$ ) are found (the first and second subtypes respectively). Similar is the case with the noun visa.

$\begin{array}{llllll}\text { bhārat me thaharne ke } & \text { unke } & \text { vize } & k \bar{\imath} & \text { miyād } \\ \text { India in stay-VN-obl GEN-m-PL 3.PL.POSSESS } & & \text { GEN-f period } \\ \text { His visa (period) [allowing] to stay in India... } & & & \end{array}$

aprail mẽ hì xatm ho cukīhai.

in EMPH end be-TERM-PRES

...ended in April.

(BBC HINDI 05/07/07)

(6)

$\begin{array}{llllllll}i s \bar{\imath} & \operatorname{ta} r \bar{x} x & k o & 2007 & m \tilde{e} & \text { unke } & \boldsymbol{v i z} \boldsymbol{e} & k \bar{\imath} \\ \text { 3.SG-DEM-OBL-EMPH } & \text { date } & \text { DAT } & & \text { in } & \text { 3.PL-POSSESS } & & \text { GEN-f }\end{array}$

With this date in 2007 his/her visa...

avadhī samāpt ho rahī thì.

period end be-PROG-PAST

...was about to expire.

(JAG 26/01/08)

(7) [..] ham amerikā āne ke lie milnevāle alag-alag kism 1.PL come-OBL for obtain+vālā-OBL different-different kind $[\ldots]$ we are now taking your questions as to what kinds...

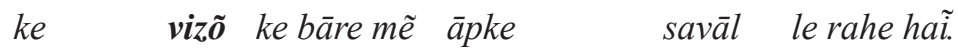
GEN-m-PL about 2.PL-POSSESS question take-PROG-PRES-PL ...of visas [are needed] to come to America.

(HI 07/05/03)

videsh̄̄ profeshanalõ ko amerikā mẽ rozgār pāne ke lie foreign DAT in employment get-OBL for

To get employed in America foreign professionals...

is $\boldsymbol{v} \overline{\boldsymbol{z}} \overline{\boldsymbol{a}}$ ko lenā partā.

3.SG-DEM OBL DAT take-VN must-PRES

...must obtain this visa.

(JAG 13/03/08)

in $\overline{\boldsymbol{v} \overline{\boldsymbol{z}} \boldsymbol{a} \tilde{\boldsymbol{o}}}$ ko anishcit kāl ke lie phirse

3.PL-DEM-OBL DAT indefinite period for again

These visas may be renewed for...

navīnīkrt kiyā jā saktā hai.

renewed $\mathrm{n}$ do-PERF can-PASS-PRES

...an indefinite period of time. 
The examples in (5) to (7) demonstrate that visa belongs to declensional subtype I (viz $\bar{a}$ -

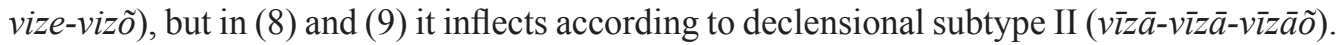

It appears that these nouns follow both declensional subtypes and thus behave in a novel and unprecedented manner. The case with visa is particularly interesting since contrary to idea, where the declension may be simply claimed to be unstable as yet, it is a long established borrowing. Such nouns normally follow either of the two decensional subtypes.

Another phenomenon in which the interplay of the two languages in question is to be observed are the derivational hybrids. KUCZKIEWICZ-FrAŚ (2000: 113) claims that apart from Perso-Arabic hybrids, there are some other hybridized items created on the base of Portugese and English, yet she argues their number to be much less than those of Perso-Arabic origin. In any case, Hindi has clearly proven susceptible to hybridization with items of langauges that it came to co-exist with. English and Hindi have not been in contact for such a long period as Hindi and Persian have, yet factually and contrary to Kuczkiewicz-Fraś claim, English-Hindi hybrids are quite frequent. Below are some of the derivational hybrids found in the corpus. ${ }^{8}$

- florāiḍukt, i.e. FLORIDE + yukt = floride-containing

rājāsthān mẽ florāidyukt pānī se hone vāli bìmārī par niyantran ke lie iske upcār $[\ldots]$

(GOOGLE HINDI)

- proținnyukt i.e. PROTEIN + yukt = containing proteins

proțīnyukt bhojan lẽ jismẽ dūdh, panīr, andā, ankurit dālẽ, taze phal ādi paryāpt mātrā mẽ hõ.

(NBT 26/12/07)

- kārbanyukt, i.e. CARBON + yukt = containing carbon; carboniferous

[...] eriyā ke àil sarkit brekar kā kārbanyukt trānsfārmar tel badalne kā kām shurū huā.

(JAG 29/10/07)

- țārneḍo-grast, i.e. TORNADO + grast = affected by tornado (region)

- ecāivī grast, i.e. HIV + grast = HIV affected

jon hovarḍ ne kahā ki ecāivī grast āpravāsiyõ yā sharṇārthiyõ ko desh mẽ āne kī anumati nahũ denī cāhiye.

(BBC HINDI 14/10/07)

- $\quad$ kainser-grast, i.e. CANCER + grast = cancer affected

is āpareshan se kainsar-grast ang ko rẹ̣ieshan se upcārit karne mẽ madad milī hai $[\ldots]$

(JAG 18/07/06)

- karfyū-grast, i.e. CURFEW + grast = curfew imposed (area)

is karfyu-grast kṣetr mẽ [...]

(DW 03/04/07)

- $\quad$ kāpīrāiț-mukt, COPYRIGHT + mukt = copyright-free

tek crañc batātā hai ki gūgal ab kāpīrāit-mukt hai.

(GOOGLE HINDI 02/01/08)

8 In this study the only contrast we draw is that of Hindi and English. Needless to say, some 'Hindi' items forming hybrids discussed here are actually of Persian or other origin. Take daftar as an example. According to SHAPIRO (2003: 274) it is an old Greek borrowing (having the sense of 'hide'/'animal skin') into Persian, from which it was borrowed into Arabic and Hindi/Urdu. It is when its sense shifted to file (a group of documents) and eventually to office (a place, where the files are stored). 
- digrī-vihīn, i.e. DEGREE + vihīn = without a degree

batāte haî ki dịgrī-vihīn ḍāktar sāhab ne use rāt ko thaṇde pānī se nahāne ko kah diyā.

(GOOGLE HINDI)

- koch-vihīn, i.e. COACH + vihīn = deprived of a coach

bhäratīya tīm shrī sharmā ke istīfe ke bād koch-vihīn hai

(DW 26/04/07)

- kārvihīn, i.e. CAR + vihīn = without car

venis yūrop sabse barāa kārvihīn ilākā hai.

(JAG 14/10/07)

- sarvekār, i.e. SURVEY + kār

rețing kī baiṭing hai, mārkețing kī ākhețing hai, sarvekārõ kī fāiṭing hai

(BBC HINDI 04/04/04)

- gaisīkaran, GAS + $\overline{1}+$ karan = gasification

gahrāì mẽ uplabdh lignāiț bhaṇ̣̂ār jo khanan yogya nah̃̃ hai, bhūmigat gaisīkaran prakriyā se [...]

(JAG 12/12/07)

- mashīnīkaran, MACHINE + $\overline{1}+$ karan = mechanization

ismẽ dikhāyā gayā hai ki mashīnīkaraṇ se kitne ādmī bekār ho jāte haĩ.

(AU 28/02/08)

- globalīkaran, GLOBAL $+\overline{1}+$ karan = globalization

kampyūțarõ kī lagātār girtī kīmat bāzār ke barthe globalīkaran aur pratispardhā mẽ tez barhotrī ki jhalak dikhātī haĩ.

(BBC HINDI 27/02/02)

- nambarīkaran, NUMBER $+\overline{1}+$ karan $=$ numerization

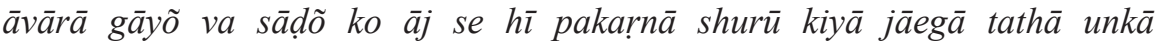
nambarīkaran kiyā jāegā.

(JAG 31/10/07)

Furthermore, there is a fair number of borrowings that appear to involve lexis along with some other levels of language. Novel grammatical patterns and alternations to UCH grammar are to be addressed below.

\section{PREPOSITION INSERTION}

As the data shows, some English-origin nouns have been inserted into the UCH with the accompanying grammatical elements originally employed in the DL. This process involves, for example, the transfer of the English preposition. As a result, UCH that is almost entirely a postpositional variety, seems to have been enriched, though still in a restricted manner, by some prepositions of English origin. ${ }^{9}$ The following examples are illustrative.

$\begin{array}{rlllll}\text { bos se zabān larā̄i to naukrī se } & \text { se } \\ \text { with tongue fight-SUBJ then job } & \text { from }\end{array}$

If you have a verbal fight with the boss, then you are out.

(NBT 11/09/07)

9 Interestingly, some prepositions have also been incorporated from Arabic, e.g. fi 'per' as in fi shakhs 'per person' or fi sadī 'per cent', now rather as fìsdī 'percent' (SHAPIRo 2003: 274) One such worthy of note example was found in the corpus as well, i.e. fì pej 'per page': ek rātri sampādak ne ek din axbār mẽ fì pej ausatan pacās xabarẽ dī thĩ (HIN 26/02/07) TIVĀRĪ, M. (1966: 86) provides some other examples invloving both native and borrowed items, e.g. fivot 'per vote' fivotar 'per voter', fidin 'per day'. These, however, seem to have gone out of use. 


$$
\begin{array}{lllll}
\text { unhẽ } & \text { mãtrī banā diyājāegā, } & \text { lekin vidāut portfoliyo. } \\
\text { 3.PL-HON DAT } & \text { minister make give-PERF-PASS-FUT but }
\end{array}
$$

He will be made a minister, but without a portfolio.

(AU 06/03/08)

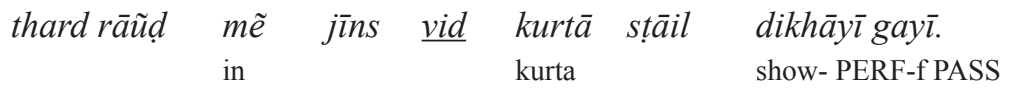

In the third round jeans with kurta style was shown.

(DBH 29/02/08)

The above examples clearly demonstrate that in the utterances produced by UCH speakers English prepositions do already co-occur with Hindi postpositions.

\section{THE INSERTION OF PREPOSITIONAL PHRASE}

The incorporation of English prepositions into the UCH is not the only pattern observable in which the embedding of prepositions does take place. Quite often, though, the embedded prepositions occur in the prepositional phrases that do not get restructured as postpositional phrases. Let us consider (13) and (14) for example.

$\begin{array}{llllllll}\text { malāl } & i \text { is } & b \bar{a} t & k \bar{a} & \text { rahnā } & \text { hai } & \text { tasvìr } & k i \\ \text { pity } & \text { 3.SG-DEM-OBL } & \text { matter } & \text { GEN-m } & \text { stay-VN } & \text { be-PRES } & \text { picture }\end{array}$

The pity is always that the picture...

$\begin{array}{llllll}\text { thhik } & n a h \tilde{\bar{l}} & \bar{a} y \bar{l} & y \bar{a} & \bar{a} u t \bar{a} f \text { fokas } & \begin{array}{l}\text { ho gay } \bar{l} . \\ \text { okay }\end{array} \\ \text { NEG } & \text { come-SIMP-PERF-f } & \text { o } & & \text { bo-SIMP-PERF-f }\end{array}$

...has come not good or out of focus.

(NBT 25/05/07)

\begin{tabular}{|c|c|c|c|}
\hline $\begin{array}{l}\text { unke } \\
\text { 3.PL-HON-POSSESS }\end{array}$ & $\begin{array}{l}\text { lie } \bar{a} u t \overline{a f f a s h a n} \\
\text { for }\end{array}$ & $\begin{array}{l}\text { ho jānā } \\
\text { be come-VN }\end{array}$ & $\begin{array}{l}\text { asambhav } \\
\text { impossible }\end{array}$ \\
\hline
\end{tabular}

It was impossible for him/her to get out of fashion.

(DW 16/04/07)

The phrases given here are of adjectival meaning. Other examples noted include out of date, out of touch, out of control, out of form and out of work.

\section{POSTPOSITION USAGE INFLUENCED BY A STRUCTURAL TRANSFER}

In a number of instances nouns, verbs and adjectives are loaned with prepositions that they concur with in the DL. These prepositions are recreated in typical for RL postpositions.

\begin{tabular}{|c|c|}
\hline focus on $\mathrm{X}$ & $\rightarrow$ X par fokas karnā \\
\hline do experiments with $\mathrm{X}$ & $\rightarrow$ X ke sāth eksparimeṇțs karnā \\
\hline involve in $\mathrm{X}$ & $\rightarrow X$ mẽ invālv honā/karnā \\
\hline research on $\mathrm{X}$ & $\rightarrow$ X par risarc karnā \\
\hline react to $\mathrm{X}$ & $\rightarrow X$ ke prati riekt karnā \\
\hline be bored with $X$ & $\rightarrow X \underline{\text { se bor honā }}$ \\
\hline depend on $\mathrm{X}$ & $\rightarrow$ X par dipend karnā \\
\hline
\end{tabular}
Compare the following. 


co-operate with $\mathrm{X}$
be addicted to $\mathrm{X}$
be busy with $\mathrm{X}$
invest in $\mathrm{X}$
deal with $\mathrm{X}$
qualify for $\mathrm{X}$

$\rightarrow \mathrm{X}$ ke sāth ko-opret karnā

$\rightarrow \mathrm{X}$ ke prati aiḍikt honā

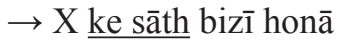

$\rightarrow \mathrm{X}$ mẽ invest karnā

$\rightarrow \mathrm{X}$ se dịil karnā

$\rightarrow X$ ke lie kvālifāā karnā

It often happens however that both native and foreign constructions are syntactically parallel, i.e. make use of identical pattern of $\mathrm{N}+$ prep./postpos. Then usually a Hindi noun is substituted for its English equivalent and thus a mixed expression originates with pattern that is only seemingly of English origin. Still, the items are combined according to syntactical rules of the RL and no novelty is introduced. The following are fine examples.

\begin{tabular}{|c|c|c|c|c|}
\hline ession & & Mixed Expression & & \\
\hline karnā & $\rightarrow$ & $\mathrm{X}$ par ațaik karnā & $\leftarrow$ & $(a$ \\
\hline lenā & $\rightarrow$ & $\mathrm{X}$ par kānsanțreț karnā & $\leftarrow$ & ate on $\mathrm{X})$ \\
\hline mpar & $\rightarrow$ & țac mẽ rahnā & $\leftarrow$ & (stay in touch) \\
\hline nāv mẽ honā & $\rightarrow$ & tenshan mẽ honā & $\leftarrow$ & (be in tension) \\
\hline
\end{tabular}

Other innovations observed in UCH involve:

- mixed conjunct verbs - the formation of analytic verb constructions which have counterparts in SH only in simple verbs (e.g. TOUCH karnā vs chūnā, TASTE karnā vs cakhnā, SELL karnā, vs becnā); large number of MCVs.

- the formation of conjunct verbs that deviate from SH linguistic convention, i.e. other components than standard nominal and adjectival $\rightarrow$ verbal, polycategorial, etc. Such differentiation of patterns in MCVs leads to reanalysis in verb formation system (e.g. dative or $\varnothing$, but no genitive postpoistions in verbal conjuncts).

- pluralization of some nouns (mainly established borrowings) either with native or borrowed means.

- introduction of nouns having both count and non-count characteristics.

- irregularities in plural forming patterns and another diversification of pluralization (either irregular plural transfer from the DL or the addition of the standard -o suffix to insertions singular in number).

- a novel pattern of comparision of adjectives - introduction of English analytic and synthetic formations (in the standard variety, native synthetic is rather obsolete, whereas analytic is more common).

- borrowing of irregular comparison of adjectives and adverbs - gradation realized lexically.

- two (native and loaned) patterns of producing participles.

- phrasal nouns $(\mathrm{N}+$ participle structures functioning as nominals, sporadically inflected according to standard patterns).

- novel postposition usages with indigenous simple and conjunct verbs as a result of semantic extensions $\rightarrow$ new patterns create new meanings or shades of meanings in indigenous lexemes. 
- word combinations calqued from the DL.

- hybrid formations involving replacement of at least one item with a loaned counterpart (hybrid collocations).

As shown above, basically no typologically disruptive innovations have been observed as yet. But from the foregoing evidence it seems clear that Englishization has irreversibly changed $\mathrm{UCH}$ in a number of ways and while being a vigorous process, it will definetely produce some other unpredictable contact phenomena in the mixed variety within the years to come.

Generally speaking, this study has shown that borrowed items being modified in various ways 'are adapted into the existing patterns' (PoPLACK et al. 1988: 62) (e.g. borrowed nouns are assigned to gender and inflected for number), which supports the previous studies on language contact phenomena. Research findings also confirm that borrowing not only may induce modifications to the syntactic and semantic properties of the foreign lexemes but also trigger alternations to the semantic and syntactic properties of some indigenous items. Again, although lexical items are clearly the most readily borrowable elements, lexical borrowing leads to structural changes as well.

The overall conclusion to be drawn from the present investigation is that the intense interaction between English and Hindi that has been taking place in Northern India results in a substantial differentiation between the (literary) standard and the mixed varieties of Hindi and is the initial step towards the creation of an interlanguage located somewhere between the two languages in question. The hybridized structure of a number of items in $\mathrm{UCH}$ and the stable and long-lived co-existence of English lexical items and Hindi grammatical morphemes may suggest that the shift to somewhat mixed variety is a process that has already begun. THOMAson (1997: 80) has defined such interlanguage (she uses the term bilingual mixed language) as a variety created in a two language contact situation involving widespread bilingualism.

What is important in the ongoing process of Hindi Englishization is the positive attitudes that exist among speakers with regard to mixed variety, the most common in urban context. As KACHRU's (1978) study shows, speakers see such code-mixing as a useful strategy, a competence, or even a good skill in communicating effectively, 'a legitimate style of informal talk' as put by GuMPERz (1982: 62). Englishized, which means prestigious variety, is thus widely accepted as an adequate style of communication for an educated urban speaker. ${ }^{10}$

\section{REFERENCES}

Alatis J.E. (ed.). 1978. Georgetown University Round Table on Languages and Linguistics. Washington, DC: Georgetown University Press.

AnNamalai Elayaperumal. 2004. "Nativization of English in India and its effect on multilingualism." Journal of Language and Politics 3(1), 151-162.

${ }^{10}$ Pandit (1986: 17) gives an example of a Hindi speaker who is not in favor of code-mixing English and Hindi in his family: 'maĩ to PURE hindī bolnā LIKE kartī hũ̃. MIX karne kā to QUESTION hī nahĩuthtā. apnī DAUGHTER aur sONS ko bhī PURE Hindī bolne ko encourage kartī hū. (I like to speak pure Hindi. The question of mixing Hindi and English does not arise. I also encourage my daughter and sons to speak pure Hindi.) (transcription standardized) Here a number of English-origin lexemes are used despite the declaration not to do so. 
Bhatia Tej K., Ritchie William C. 2005. The Handbook of Bilingualism. Oxford: Blackwell.

CARDona George, Jain Dhanesh (eds.). 2003. The Indo-Aryan Languages. London-New York: Routledge.

Gumperz John J. 1982. Discourse Strategies. Cambridge: Cambridge University Press.

Highfield A., Valdman A. (ed.). 1981. Historicity and Variation in Creole Studies. Ann Arbor: Karoma, 52-78.

KaChru Braj B. 1978. "Code-mixing as a Communicative Strategy in India." In: Alatis 1978: 107-124.

Kachru Braj B. 1986. The Alchemy of English: The Spread, Functions and Models of Non-native Englishes. Oxford: Pergamon Press.

Kachru Braj B. 1994. "Englishization and Contact Linguistics.” World Englishes 13, 135-154.

KaCHRU Yamuna. 1989. “Corpus Planning for Modernization: Sanskritization and Englishization of Hindi.” Studies in the Linguistic Sciences 19(1), 153-164.

Krishnamurti Bhadriraju, Masica Collin P., Sinha Anjani K. (eds.). 1986. South Asian Languages. Structure, Covergence and Diglossia. Delhi: Motilal Banarsidass.

Kuczkiewicz-Fraś Agnieszka. 2000. "Perso-Arabic Hybrids in Hindi." Zeszyty Naukowe Uniwersytetu Jagiellońskiego MCCXLI, 113-119.

Muysken Pieter. 1981. "Halfway between Quechua and Spanish: The Case for Relexification." In: Highfield \& VALDMAN 1981: 52-78.

Myers-Scotton Carol. 2002. Language Contact: Bilingual Encounters and Grammatical Outcomes. Oxford: Oxford University Press.

Pandit Ira. 1986. Hindi English Code Switching. Mixed Hindi English. Delhi: Datta Book Centre.

Patnaik B.N., Pandit Ira. 1986. "Englishization of Oriya." In: Krishnamurti et. al. 1986: 232-243.

Poplack Shana, Sankoff David, Miller Christopher. 1988. "The Social Correlates and Linguistic Processes of Lexical Borrowing and Assimilation." Linguistics 26, 47-104.

SANKoff Gillian. 2001. "Linguistic Outcomes of Language Contact.” In: TrudgiLL et al. 2001: 638-668.

Shapiro Michael. 2003. 'Hindi.' In: CARDONA \& JAIN 2003: 250-285.

SHETTY Malavika. "Language Contact and the Maintenance of the Tulu Language in South India." Texas Linguistic Forum 47, 183-195.

SRIDHAR S.N., SRIDHAR K. 1980. "The Syntax in Psycholinguistics of Bilingual Code Mixing.” Canadian Journal of Psychology 34, 407-416.

Stasik Danuta. 1994. Podręcznik języka hindi. Vol. 1. Warszawa: Dialog.

StAsIK Danuta. 1997. Podręcznik języka hindi. Vol. 2. Warszawa: Dialog.

STASIK Danuta. 1998. Język hindi. Warszawa: Dialog.

Thomason Sarah G. (ed.). 1997. Contact Languages: A Wider Perspective. Amsterdam: John Benjamins.

Thomason Sarah. G. 2001. Language Contact. Washington, D.C.: Georgetown University Press.

Thomason Sarah G., Kaufman Terrence. 1988. Language Contact, Creolization and Genetic Linguistics. Berkeley: University of California Press.

Tivārĩ Manoj. 1966. Hindī bhāṣā par fārsī aur ãgrezī kā prabhāv (Persian and English influence on Hindi). Benaras: Nagari Pracharani Sabha.

Trudgill P., Chambers J., Schilling-Estes N. (ed.) 2001. Handbook of Sociolinguistics. Oxford: Basil Blackwell. Verma Shivendra. K. 1976. “Code-Switching: Hindi-English.” Lingua 38, 153-165.

WeInREICH Uriel. 1953/1968. Languages in Contact: Findings and problems. New York: Linguistic Circle of New York. [Reprinted 1986]. The Hague: Mouton.

Winford Donald. 2003. An Introduction to Contact Linguistics. Blackwell Publishing, Ohio State University.

ZABROCKI Ludwik. 1963. Wspólnoty komunikatywne w genezie i rozwoju języka niemieckiego. Wrocław: Zakład Narodowy im. Ossolińskich. 